\title{
Analysis on the Importance of Mother Tongue in Early Childhood
}

\author{
Faizatul Faridy, Ernawulah Syaodih
}

Universitas Pendidikan Indonesia, Bandung, Indonesia

Corresponding e-mail: Faizatul248@gmail.com

\begin{abstract}
The number of population movements, cross-marriages, and current globalization cause the use of vernacular or local language as mother tongue diminishes. In addition to the vernaculars threatened with extinction due to the lack of speakers, the values contained in the local languages are lost and not passed on to the following generation. This study was conducted to analyse what role the mother tongue takes in the early childhood, as well as to reveal any obstacles and constraints encountered by parents in using mother tongue outside their hometown. Qualitative research with the case study method was conducted in this research. This study was conducted randomly on parents from Aceh who currently live in Bandung. The findings show that parents assume when they leave their hometown the use of local language as mother tongue is considered not needed by their children. It also reveals a strong correlation between the mother tongue with the environment where the children live, mother-son attachment, as well as the children's love of their culture and homeland. Given the tremendous role of mother tongue in early childhood, the researcher put the interest into this article in order to broaden the parents and society the importance of using mother tongue as the basis for the young children.
\end{abstract}

Keywords: mother tongue, the role of mother tongue

\section{INTRODUCTION}

Mother tongue (first language) has a great influence on children, particularly in their second language acquisition. This is corroborated by Behaviourist theory by Skinner (1957), which argues that language is the result of stimulus-response. Thus, when children learn their mother tongue, which in Indonesia are mostly local languages or vernacular, it will facilitate the children in learning other languages. It is also because the local language has a rich vocabulary that does not exist in any language, so that children who master the mother tongue as a first language tend to have more vocabulary than their national language. Moreover the use of local languages contains norms that make up the speaker. For example, in the local language each word will be used differently in accordance with to whom the speaker talk to. If it is to show respect or when speaking to older people, a more polite language tend to be used, and the same statement will be delivered differently to closer relatives or younger interlocutors. This makes the speaker understand the importance of respecting their interlocutors.

Notwithstanding the use of vernacular or local language as mother tongue is becoming obsolete in society. Holmes (2013) notes in his book that there are several factors of why the use of local language begins to wane; among others are the minorities, cross-marriages, and immigration or population movements. No to mention, young families affected by trends which tend to adopt national language into daily language of instruction with their children, whereas there are lots of positive impacts the children could obtain from the use of local language as their mother tongue.

The author concludes that mother tongue play an important role both in preserving the local language and facilitating children to acquire second and third languages, and even establishing attachment between the children and their mother. Some previous studies have been conducted regarding languages; however this research is leading mainly to the language interference, not the mother tongue. As for a journal by Nurdin and Gio (2013), which discuss vocabulary interference of 
Cirebon language against Indonesian in the writings of primary school students, and a thesis by Fuad (2015) on Language Attitude of Primary School Students against Local Language and Bahasa Indonesia. Fuad stated that there is interference of Sundanese (local language) on the children from Aceh who live in Bandung. The author also found a number of journals that discuss mother tongue, as research conducted by Morra (2007) who expressed disappointment in his writing as the mother tongue used in movie theatres (in French) were translated into the national language which was English. Several other studies emphasize that the minorities out there still use their mother tongue to preserve their local languages. Indonesia, which has a diversity of local language as the mother tongue, would be more interesting to study. Therefore the author put the interest to figure out the use of mother tongue of Indonesian early childhood.

Accordingly, the formulation of the research problem is as follows.

1. What is the role of mother tongue in early childhood?

2. If any, what supporting /inhibiting factors encountered by the parents, mother in particular, in the habituation of mother tongue use to their young children?

\section{LITERATURE REVIEW}

\subsection{Language}

In Kamus Besar Bahasa Indonesia (2001) language is defined as an arbitrary sound system that is used by the members of a society to interact, communicate, establish coordination, and identify among themselves. The same term is also described in Kamus Linguistik (2001) in which English is the epitome of arbitrary sound system used by the members of a community as a means of communication, coordination, and selfidentification. From those definitions, it can be said that language is a means of communication in the form of sound system symbol generated by human's vocal organs. Language itself may consist of words or set of words each of which has meaning. The absence of language (including Bahasa Indonesia) may lead to the underdevelopment of science and technology (Sunaryo, 2000). Besides Bahasa Indonesia has particular position, function, and dual role as the root as well as cultural product in cultural structure that also functions as a means of thinking and as support for science and technology development. Without those roles, science and technology will not be able to develop. The implication is in the development of the power of reason in which language is a medium of modern thinking. Therefore, the punctilio of using a language will lead to the precisions of ways of thinking since language is the mirror of the mind.

\subsection{Mother Tongue}

According to Sontag \& Wallace (1936) in Matthew (2010), the first ever functioned of the five senses is auditory. A sound that a new-born baby hears for the very first time is his mother's voice. This is because the mother used to talk to her baby in her womb, hence the term mother tongue. Based on KBBI (Kamus Besar Bahasa Indonesia), "The mother tongue is the first language that a person obtains right after he was born through the interaction from his society, family and his surroundings". Tarmizi proclaimed, the child can only acquire certain language by mastering the mother tongue in the first place.

There are several controversies regarding the very definition of the mother tongue itself. Some people believe that the mother tongue is part of local language, while some others do not. Ajip Rosidi cited in his book entitled Bahasa Indonesia Bahasa Kita: Akan Diganti dengan Bahasa Inggris? (2010), conceived that people commonly define the term of mother tongue as vernacular or local language.

However, he believes that vernacular language is not quite appropriate in referring to the mother tongue. This is due to the fact that those languages, the mother tongue, do not belong to a particular domain. This leaves vernacular as the language that belongs to certain regions. Then again, this vernacular, which is supposed to be used in certain area, has also been exercised outside the domain. In other words, that particular society has practiced their mother tongue instead of vernacular language. Ali (1995) stated that the mother tongue is the language that has been acquired through social interaction that involves the speaker's family and neighborhood. This suggests the first language (B1) is an early process gained from identifying the sound and sign called language. Quite on the contrary, some people reckon that the mother tongue is different from the first language. Dardjowidjojo (2014) distinguishes the two terms: mother tongue and mother's language. He said, the mother tongue is the first language that the child learns; be that it is English, Indonesian, or even vernacular. While the latter, mother's language, is the language used by adults or 
parents to communicate with their children, whom are trying to acquire the mother tongue.

Therefore, according to the aforementioned theorists, it can be said that the mother tongue is the basic language that is first introduced by the parents to their children through daily interactions. In Indonesia, the mother tongue tends to be identified as vernacular or local language. This comes as a result of ethnic diversity. The vernacular language has become more attached to Indonesian daily life, making the mother tongue to merge with the vernacular language. The first language itself here defined as the language that could unite or unify various regions from different vernacular languages. In this country for instance, Indonesian language serves as the unifying language.

\subsection{Variety of Mother Tongue}

Indonesia is a great nation; not only in its abundant natural resources but also in its very unique and diverse cultures. The diversity of customs, languages, and dialects affects the diversity of mother tongue in Indonesia. In 2008 the number of languages in the world reached 6.912 languages. Indonesia ranks second (741 languages) after Papua New Guinea (820 languages). Most of the 741 languages are local languages or vernaculars, in which Javanese becomes the language with the most speakers. In Summer Institute of Linguistics (2006) is stated the ranking of the languages by the number of speakers in Indonesia. The data show that there are 75.6 million speakers of Javanese, 27 million of Sundanese, 17.1 million of Indonesian (140 million as the second language), 13.7 million of Madura language, 6.5 million of Minangkabau, 6.2 million speakers of Batak language, 3.8 million of Balinese Bugis language of less than 4 million speakers, Aceh with 3 million speakers of the language,

Betawi/creole with 2.7 million speakers, Sasak with 2.1 million speakers, 2 million speakers of Makassar language, less than 1.5 million speakers of Lampung language, and less than 1 million speakers of Rejang language.

Due to the lack of time, funds, and many other factors, the researcher could only gather some people from Aceh who are currently living in Bandung as the samples. The selections of samples are mainly influenced by the researcher's background. As it stands, the researcher is also from Aceh, which means, the researcher has been familiar with their custom. By having similar background, the researcher wishes to have in-depth findings on the research problems.

\section{METHOD}

Case study with qualitative method was employed in this study. The research was conducted in Bandung, west Java. The selections of samples are mainly influenced by the researcher's background. As it stands, the researcher is also from Aceh, which means, the researcher has been familiar with their custom. By having similar background, the researcher wishes to have in-depth findings on the research problems. In this research, the researcher had selected the children who have Aceh decent from various family backgrounds, assuming that the results would be in more diverse. Some parents of the participants are from Aceh, while some others have different lineage. The numbers of selected participants are five to eight families in total.

\section{FINDINGS AND DISCUSSION}

Based on observations and interviews with a number of families from Aceh who were currently living in Bandung about Aceh language as their mother tongue, it obtained the findings as follows.

First is the parents understanding of mother tongue. Mostly the parents considered mother tongue as vernacular or local language from their origin, while the rest conceived that mother tongue was the first language acquired by the children and it was specified from where the children live and not where they were from. Secondly, six of eight families surveyed used Bahasa Indonesia as their mother tongue. They considered that Acehnese as mother tongue or native language was not required by their children. This was due to the assumption that the children are not going to use Acehnese while staying in other community. In addition the parents said that the children will eventually learn their own local language of Aceh when they return to their homeland. Besides, the parents also assumed that the language skills of their children were not merely their responsibility, but the surroundings' as well. Let the society teach and shape them.

Third, some of the families introduced Aceh to their children through language, cuisine, and histories of Aceh with the result that the children could eventually love Aceh as their region of origin. Fourth, Sulit Checklists verified vernacular or local language as native language or mother tongue when someone need to deal with several conditions such as being in a region operation, cross marriage, and educational institutions that did not tolerate and accommodate the difference in ethnicity and culture. 
Fifth, the children were easily and fast affected by their surroundings or environment, one of which is the dialect used and language mastered by the children. Lastly, the use of vernacular or local language by the parents (the mother in particular) mostly occurred when expressing full of emotional feelings of ideas addressed to their children that could not be delivered through any language.

\section{CONCLUSION}

Based on the research results, it can be concluded that indeed parents are actually aware of the importance of implementing the use of local language as mother tongue. However, parents find much difficulty in using local language as their mother tongue especially when living away from homeland. It is due to the fact that at school the children learn the local language existed in their current circumstance that is not theirs, in the other words they have to master other people's local language. In addition, learning own local language as mother tongue will be more challenging for a young child if there is no support from family and surroundings.

Local language is appropriate to be used as mother tongue since they contain elements of emotional, cultural, spiritual, and custom specialty of a society. So not only as a means to communicate, the mother tongue forms the speakers as well.

Neighbourhood, school, and parents are three important foundations to shape young children. Thereof the use of local language as mother tongue will be strongly influenced by the language used by the parents at home, the language the children obtained from the environment, and the role of school in accommodating differences of the children's ethnic and cultural backgroundTable rences of the children's ethnic and cultural background.

\section{REFERENCES}

Ali L. (2001). Kamus Besar Bahasa Indonesia. Jakarta: Balai Pustaka.

Ali L., dkk.(1995). Kamus Besar Bahasa Indonesia. Jakarta: Balai Pustaka.

Carmona M., et. al. (2010). Public Place Urban Space: The Dimention Of Urban Design. New York: Elsevier.

Dardjowidjojo Soenjono.Psikolinguistik Pengantar Pemahaman Bahasa Manusia: Yayasan Obor Indonesia, 2014.
Daud B. (2006). Bahasa Dan Sastra Aceh: Milik Siapa? Fakultas Keguruan dan Ilmu Pendidikan (FKIP) Universitas Syiah Kuala, Banda Aceh.http://herocay.blogspot.com. Diakses : 19 April 2016.

Holmes R. M., Liden S., Shin L. (2013).“Childern's Thinking Styles, Play, and Academic Performance". American Journal of Play.

Joanne M. (2007). Daughter's Tongue: The intimate Distance of Translation. Journal of Visual Culture. Vol 6(1):91-108 Sage Publication.

Kridalaksana, H. (2001). Kamus Linguistik. Jakarta:

PT Gramedia Pustaka Utama

Nurdin M.N., Gio M.J (2013) Interferensi Kosakata Bahasa Cirebon Terhadap Bahasa Indonesia Dalam Karangan Siswa Sekolah Dasar. Jurnal Pedagogik Pendidikan Dasar. Bandung.

Rosidi A. (2010). Bahasa Indonesia Bahasa Kita; Akan Diganti Dengan Bahasa Inggris. Pustaka Jaya. Jakarta

Tarmizi. (2009). Pola asuh orang tua dalam mengarahkan perilaku anak.(Online),http://tarmizi.wordpress.com/201 6/04/26/pola-asuh-orang-tua-dalam mengarahkan-perilaku-anak/

Zaki A. (2015). Sikap Siswa SD Terhadap Bahasa Daerah Dan Bahasa Indonesia. (Tesis). Sekolah Pascasarjana, Universitas Pendidikan Indonesia, Bandung

https://www.google.co.id/url?sa=t\&rct=j\&q=\&esrc= $\mathrm{s} \&$ source $=$ web $\& \mathrm{~cd}=6 \& \mathrm{cad}=\mathrm{rja} \&$ uact $=8 \& \mathrm{ved}=$ 0ahUKEwivlKrYt7bPAhUDLpQKHRQ9ASU QFgg8MAU\&url=https\%3A\%2F\%2Fkangrian. files.wordpress.com\%2F2011\%2F01\%2Fpemb ahasan-fungsi-dan-kedudukanbi2.docx\&usg=AFQjCNHUq7x0Qo9aVdJt1Ju wqPIPwW-Mrw\&sig2=r5CdIz_xwGtY7LZEIvC9A (2016/09/30)

Wildan. (2002). Kenakalan Remaja. http://www.skma.org/tutor/pe rilaku/kenakalanremaja.pdf. (10 April 2016) 